\title{
Cultivation of Mexican wild strains of Agaricus bisporus, the button mushroom, under different growth conditions in vitro and determination of their productivity
}

\author{
Dulce Salmones, Rigoberto Gaitan-Hernandez, Gerardo Mata
}

Institute of Ecology. Biotechnological Management of Resources Network. P. O. Box 63. Xalapa, Veracruz (Mexico). E-mail: gerardo.mata@inecol.mx

Received 17 May 2017, accepted 17 October 2017, available online 7 December 2017.

This article is distributed under the terms and conditions of the CC-BY License (http://creativecommons.org/licenses/by/4.0)

Description of the subject. Edible mushrooms cultivation is one of the most important agro-industries in Mexico, showing good impact on food production through a controlled biotechnological process. National production is supported by foreign strains although this region has a great biological diversity in wild mushrooms species with adaptatively advantages to the local environment, but these genetic resources have been few studied, especially for Agaricus species.

Objectives. To unravel the potential of wild Mexican strains of Agaricus bisporus for the production of fruiting bodies on compost.

Method. The mycelial growth rate of eight A. bisporus strains (two wild, six commercial) in culture media was assessed by supplementing a malt extract medium with yeast extract (YMEA), yeast extract and indulin AT (YMEA-indulin AT), and compost extract (CMEA) at three different incubation temperatures $\left(22,25\right.$ and $\left.28^{\circ} \mathrm{C}\right)$. Mycelial growth was evaluated in solid media $\left(\mathrm{mm} \cdot \mathrm{day}^{-1}\right)$ and liquid culture (decrease in the phenol content). Four strains (two wild, two commercial) with the best in vitro results were selected to obtain carpophores on compost and evaluate their yields.

Results. The highest values of mycelial growth were observed in CMEA and the greatest decrease in phenol content was recorded for YME. Biological efficiencies of the four selected strains were 50.8 to $95.5 \%$, and yields were 7.4 to $14.1 \mathrm{~kg} \cdot \mathrm{m}^{-2}$ in crop cycles of 74 to 98 days. Basidiomes 5 to $15 \mathrm{~cm}$ in diameter predominated.

Conclusions. The characteristics of the wild strains indicate their suitability for the regional market, but additional experiments are necessary to improve their productivity parameters.

Keywords. Agaricus bisporus, germplasm, in vitro, growth, indigenous organisms.

Culture de souches sauvages mexicaines d'Agaricus bisporus, le champignon de couche, sous différentes conditions de croissance in vitro et détermination de leur productivité

Description du sujet. La culture de champignons comestibles est une des industries agroalimentaires les plus importantes du Mexique et cette activité montre un bon impact sur la production alimentaire grâce à un procédé biotechnologique contrôlé. La production nationale est soutenue par des souches étrangères, bien que cette région présente une grande diversité biologique d'espèces de champignons sauvages avec des avantages adaptatifs pour l'environnement local, mais ces ressources génétiques ont été peu étudiées, en particulier pour les espèces d'Agaricus.

Objectifs. Étudier le potentiel de souches sauvages d'Agaricus bisporus isolées au Mexique afin de produire des champignons dans les conditions locales de culture sur compost.

Méthode. Les taux de croissance mycélienne de huit souches d'A. bisporus (deux sauvages et six commerciales) ont été évalués dans différents milieux de culture en complétant un extrait de malt avec de l'extrait de levure (YMEA), de l'extrait de levure et de l'induline AT (YMEA-indulin AT) et de l'extrait de compost (CMEA) à trois températures d'incubation différentes $\left(22,25\right.$ et $28^{\circ} \mathrm{C}$ ). La croissance du mycélium a été évaluée en milieu solide ( $\mathrm{mm}$ par jour) et liquide (diminution de la teneur en phénol). Les souches les plus vigoureuses ont été évaluées pour leur rendement de production de sporophores sur compost. Résultats. Les valeurs les plus élevées de croissance ont été observées dans le milieu CMEA et la plus forte baisse en teneur de phénol a été enregistrée pour YME. L'efficacité biologique de deux souches sauvages mexicaines et de deux souches commerciales variait entre 50,8 et $95,5 \%$ et le rendement était de 7,4 à $14,1 \mathrm{~kg} \cdot \mathrm{m}^{-2}$ pour des cycles de culture de 74 à 98 jours. Le calibre des champignons de 5 à $15 \mathrm{~cm}$ dominait. 
Conclusions.Les caractéristiques des souches sauvages indiquent qu'elles possèdent un potentiel intéressant pour l'introduction sur le marché régional, mais des expériences supplémentaires sont nécessaires pour améliorer les paramètres de productivité. Mots-clés. Agaricus bisporus, germplasm, croissance, in vitro, organisme indigène.

\section{INTRODUCTION}

Agaricus bisporus (Lange) Imbach, the white button mushroom, currently holds fourth place in commercial mushroom production worldwide (Royse \& Sánchez, in press). It is grown commercially in at least 90 countries, with an estimated annual production of more than 4 million tons (Sonnenberg et al., 2011; Royse, 2014). Despite the economic importance of this species, until the end of the last century it was believed that wild A.bisporus populations were restricted to the European continent where the species had been domesticated (Savoie et al., 2013). This concept of distribution changed in the 1980's when native specimens of this species were found in North America, including California and Canada, or Asia (Callac et al., 2005). Subsequently, its distribution was extended to Mexico by Mata \& Rodríguez-Estrada (2005) who collected wild specimens in a disturbed Cupressus forest in central Mexico, and recently it was demonstrated that these specimens do not correspond to any commercial strain under cultivation (Mata et al., 2016). The habitat of A. bisporus is known to extend from the boreal region of Alaska (Geml et al., 2008 ) to the equatorial climate of the Congo, and from coastal dunes to mountains over $3,000 \mathrm{~m}$ in elevation (Largeteau et al., 2011). According to Savoie et al. (2013), in spite of the wide geographic distribution of this species in the world, the geographic diversity of this species is not reflected in the preserved germplasm.

In Mexico, as in other Latin American countries, mushroom cultivation was introduced in the 1930's, with technology brought by European migrants (Martínez-Carrera \& López-Martínez de Alva, 2010). During the early years, the national production of this mushroom was unstable, fluctuating notably, though it did increase during the final two decades of the last century. By 2014, national production of A. bisporus was estimated at 59,349 tons, representing $93.7 \%$ of total national edible mushroom production, maintaining leadership among Latin American countries (MartínezCarrera et al., 2016). To date, Mexican production depends on foreign strains.

Agaricus bisporus is a humicolous saprotrophic fungus that grows on plant organic matter previously transformed by other microorganisms, and consequently it is cultivated on compost. An essential step in successful commercial cultivation is determining the nutritional factors that are necessary to optimize mycelial vegetative growth. This physiological stage requires the fungus to be able to produce extracellular lignocellulolytic enzymes to degrade three main components of these complex organic matrices: lignin and humic compounds, complex carbohydrates (cellulose and hemicellulose), and organic sources of nitrogen (Hildén et al., 2013; Patyshakuliyeva et al., 2013). The in vitro mycelial development exhibited by the strains is one of the most important factors in selection of germplasm for their cultivation, because the growth medium provides the necessary nutrients for mycelial growth and the formation and development of carpophores (Mantovani et al., 2007).

On the other hand, the search for A.bisporus strains tolerant to high temperatures is still underway (Wang et al., 2004; Nogueira de Andrade et al., 2010; Largeteau et al., 2011), since maintaining a controlled environment in modern facilities requires energyconsuming cooling systems. Thus, in the context of sustainable agriculture and given the economic expansion of emerging countries, the development of A. bisporus cultivated strains that are able to fruit at higher temperatures than the current cultivars represent a promising alternative for reducing energetic costs during cultivation in hot countries and in temperate countries when summer temperatures are high (Navarro $\&$ Savoie, 2015). Our objectives were to attain a better understanding of the adaptation of Mexican wild A. bisporus strains under different growth conditions (medium and temperature) in vitro, in comparison to commercial strains, and to select A.bisporus isolates amenable to warm environmental conditions, without compromising the quality of the mushrooms harvested.

\section{MATERIALS AND METHODS}

\subsection{Mushroom strains}

Eight strains of A.bisporus from commercial spawn producers were studied: IE-273 (305 MISPAJ), IE-751 (Delta, AMYCEL), IE-752 (Phoenixx, AMYCEL), IE-754 (365 MISPAJ) and IE-755 (45 GURELAN); IE-610 (HAI 24) was provided by the Culture collection of Higher Basidiomycetes of the Institute of Evolution (HAI), University of Haifa, Israel; and IE-623 and IE-746 were field isolates from the state of Tlaxcala, Mexico, in semi-dry temperate climate, where they were growing on the litter of Cupressus benthamii (Mata \& Rodríguez Estrada, 2005). Mycelia of all strains are maintained in the Fungus Ceparium 
of the Institute of Ecology, A.C. in Xalapa, Mexico (WDCC 789).

\subsection{Mycelial growth on different basal media and temperatures}

Strains were grown on Petri dishes $(90 \mathrm{~mm} \varnothing)$ containing $20 \mathrm{ml}$ of the following culture media:

- malt extract agar (MEA, Bioxon: $20 \mathrm{~g} \cdot \mathrm{l}^{-1}$ malt extract, $15 \mathrm{~g} \cdot \mathrm{l}^{-1}$ agar),

- yeast malt extract agar (YMEA, Bioxon: $20 \mathrm{~g} \cdot \mathrm{l}^{-1}$ malt extract, $2 \mathrm{~g} \cdot \mathrm{l}^{-1}$ yeast, $15 \mathrm{~g} \cdot \mathrm{l}^{-1}$ agar),

- yeast extract malt agar with commercial kraft lignin added (YMEA-indulin AT: $20 \mathrm{~g} \cdot \mathrm{l}^{-1}$ malt extract, $2 \mathrm{~g} \cdot \mathrm{l}^{-1}$ yeast, $15 \mathrm{~g} \cdot \mathrm{l}^{-1}$ agar, $3 \mathrm{~g} \cdot \mathrm{l}^{-1}$ indulin AT dissolved in $800 \mathrm{ml}$ of distillated water and adjusted to $1 \mu \mathrm{mol}$ concentration of phenols),

- compost malt extract (CMEA: $10 \mathrm{~g}$ malt extract. $600 \mathrm{ml}^{-1}$ compost extract and $400 \mathrm{ml}$ distillated water adjusted to $1 \mu \mathrm{mol}$ concentration of phenols).

For the preparation of compost extract, $300 \mathrm{~g}$ of fresh compost was added to $1,000 \mathrm{ml}$ of distilled water and the mixture was heated to boiling for $20 \mathrm{~min}$. After the cooling, mixture was filtered through two layers of muslin to recover approximately $800 \mathrm{ml}$ of infusion, then the concentration of phenols was adjusted by the addition of distilled water. Culture media were sterilized at $121^{\circ} \mathrm{C}$ for $20 \mathrm{~min}$. Each Petri dish was inoculated in the center with a $0.5 \mathrm{~cm}$ diameter disc of previously uniformly colonized MEA of one strain and incubated at 22,25 and $28^{\circ} \mathrm{C}$, in the dark. Every two days over the 14 days of incubation, mycelial growth rate was estimated based upon culture mycelia diameter, recorded in two perpendicular directions. All experiments were carried out with eight replicates.

\subsection{Effect of strain and temperature on the degradation of lignin-derived phenol content in different basal media}

For this test, the A. bisporus strains were cultivated in $100 \mathrm{ml}$ Erlenmeyer flasks containing $20 \mathrm{ml}$ liquid yeast malt (YME) or compost malt extract media (CME). The culture media were prepared as for the mycelial growth experiment but without adding agar. Each flask was inoculated with a $0.5 \mathrm{~cm}^{2}$ plug of mycelia on agar and incubated under static conditions at 22, 25 and $28{ }^{\circ} \mathrm{C}$. After 14 days of incubation, the culture was filtered through Whatman No. 1 filter paper and the phenols present in the filtrate were determined by adding Folin and Ciocalteu reagent (Box, 1983). After $1 \mathrm{~h}$ of incubation at room temperature, absorbency was read at $750 \mathrm{~nm}$ and the results expressed in $\mu \mathrm{mol}$ of water soluble phenols per $\mathrm{ml}$ of solution.

\subsection{Spawn preparation}

Based on the results of the laboratory analyses, four A. bisporus strains (IE-610, IE-623, IE-746 and IE-754) were selected to evaluate their productivity on compost. Spawn was prepared in polyethylene bags containing $200 \mathrm{~g}$ of hydrated sorghum grains mixed with $0.5 \%$ (dry weight) of a 1:1 mix of calcium carbonate and calcium sulfate, and autoclaved at $121^{\circ} \mathrm{C}$ for $90 \mathrm{~min}$. Sterilized grains were inoculated with a plug of a pre-cultured A. bisporus strain and incubated at $25{ }^{\circ} \mathrm{C}$ in darkness until the grains were completely covered by mycelia (approximately two weeks). Spawn was stored at $4{ }^{\circ} \mathrm{C}$ in darkness.

\subsection{Mushroom production}

Agaricus bisporus strains (IE-610, IE-623, IE-746 and IE-754) were cultivated in boxes $\left(936 \mathrm{~cm}^{2}\right.$ in area) filled with $4 \mathrm{~kg}$ of phase II mushroom compost made by a mushroom grower and spawned at 5\%. The compost was produced from wheat straw (65\%), chicken manure $(25 \%)$, sugar cane bagasse $(9 \%)$ and urea $(1 \%)$, at $\mathrm{pH} 8.1$ and $66 \%$ moisture. Each box was covered with plastic sheets. Eight samples were prepared with each strain.

After 20 days of incubation at $25 \pm 1^{\circ} \mathrm{C}$, boxes colonized by A.bisporus were covered with a $4 \mathrm{~cm}$ casing layer composed by peat moss $(8 \%)$ and limestone (92\%). Five days after casing, the surface of the casing soil was ruffled deeply. Fresh air was then introduced into the growing room to lower the ambient temperature to $22 \pm 1{ }^{\circ} \mathrm{C}$. One day later, the growing rooms were ventilated to stimulate the production of carpophores. Irrigation of the culture started when carpophores had reached the primordium size stage and a RH of $85-90 \%$ was maintained throughout cropping.

Mushrooms were harvested during the first three flushes and earliness was expressed as the number of days elapsing between spawning and the harvesting of the first flush. The strains' productivity was expressed as biological efficiency (ratio of fresh mushroom weight harvested to dry compost weight, expressed as a percentage), yield ( $\mathrm{kg}$ of fresh mushrooms weight per square meter), production rate (ratio of biological efficiency to culture cycle days, expressed as a percentage). With the aim to know the maximum sizes of pileus development, the mushrooms were harvested after the cap was opened and the mushrooms were separated according to size into four groups, G1: $\leq 5 \mathrm{~cm}, \mathrm{G} 2: 5.1$ to $10 \mathrm{~cm}, \mathrm{G} 3: 10.1$ to $14,9 \mathrm{~cm}, \mathrm{G} 4$ : $>15 \mathrm{~cm}$, following the classification established by Gaitán-Hernández et al. (2014) and expressed as a percentage. Cap color was scored as: 1: white, 2: light brown and 3: brown. 


\subsection{Statistical analysis}

A completely random design with a factorial arrangement was applied to mycelial growth and the effect of strains and temperature on the degradation of lignin-derived phenols contained in different basal media. The mushroom production experiments were arranged as a completely random design. An analysis of variance (ANOVA) was conducted on all values and means were compared using Tukey's and Duncan's tests $(p<0.05)$ run in the statistical software Statistica (v. 7.0).

\section{RESULTS AND DISCUSSION}

\subsection{Mycelial growth on different basal media and at different temperatures}

The results of the mycelial growth of the strains under different conditions are presented in tables 1, 2 and 3. The daily increase in the mycelial diameter of the different strains varied with temperature and culture media tested, but in general, the strains growing in CMEA had the highest values. With respect to the temperature parameter, at $22^{\circ} \mathrm{C}$ the highest mycelial growth rates on CMEA were recorded for the two Mexican wild strains (IE-623 and IE-746), followed by some commercial strains (IE-610, IE-752, IE-754 and IE-755), but without any statistical differences between the two types of strains (Table 1).When strains were cultured at $25^{\circ} \mathrm{C}$ (Table 2), the Mexican strain IE-746 had a good mycelial growth in all of the culture media evaluated, while the other wild strain (IE-623) only maintained good growth in CMEA. For the remaining strains (except IE-273), the highest mycelial growth rate occurred on CMEA. Similar to the previous incubation condition, the strains cultivated at $28{ }^{\circ} \mathrm{C}$ on CMEA had the highest mycelial growth rates (except IE-273), and the remaining averages were not statistically different. In addition, both Mexican strains had good mycelial growth in MEA and YMEA-indulin AT (Table 3). In previous work, Martínez-Carrera et al . (2001) cultivated a Mexican wild strain of A. bisporus var. bisporus on MEA and registered mycelial growth rate from 0.12 to $0.20 \mathrm{~cm} \cdot \mathrm{day}^{-1}$, at $25^{\circ} \mathrm{C}$. These values are lower than those reported in the present study.

With respect to the pattern by strain, the wild strain IE-746 is noteworthy for its high adaptability to the different supplements of the culture media and the incubation temperatures tested; particularly at $25{ }^{\circ} \mathrm{C}$, where mycelial increase in this wild strain did not differ from that of the commercial strains. The other Mexican wild strain, IE-623, had good mycelial growth in CMEA samples, regardless of the incubation temperature. In contrast and under the parameters
Table 1. Mycelial growth rates $\left(\mathrm{mm} \cdot \mathrm{day}^{-1}\right)$ obtained by Agaricus bisporus strains on different culture media at $22{ }^{\circ} \mathrm{C}$ - Taux de croissance mycélienne $\left(\mathrm{mm} \cdot\right.$ jour $\left.^{-1}\right)$ des souches d'Agaricus bisporus sur différents milieux de culture à $22{ }^{\circ} \mathrm{C}$.

\begin{tabular}{lllll}
\hline Strain & MEA & YMEA & $\begin{array}{l}\text { YMEA- } \\
\text { indulin } \\
\text { AT }\end{array}$ & CMEA \\
\hline Wild & & & \\
IE-623 & $2.7 \pm 1.2^{\text {bc }}$ & $2.3 \pm 0.7^{\text {b-d }}$ & $2.7 \pm 0.7^{\text {b-d }}$ & $6.4 \pm 2.3^{\mathrm{a}}$ \\
IE-746 & $3.5 \pm 0.6^{\text {ab }}$ & $2.8 \pm 0.6^{\text {b-d }}$ & $2.9 \pm 1.3^{\text {bc }}$ & $5.4 \pm 1.9^{\mathrm{a}}$ \\
\hline Commercial & & & \\
IE-273 & $1.4 \pm 0.2^{\text {cd }}$ & $1.7 \pm 0.3^{\text {cd }}$ & $1.1 \pm 0.3^{\text {d }}$ & $2.7 \pm 0.6^{\text {b-d }}$ \\
IE-610 & $2.7 \pm 0.7^{\text {b-d }}$ & $3.0 \pm 0.9^{\text {bc }}$ & $1.7 \pm 0.6^{\text {cd }}$ & $5.8 \pm 2.3^{\text {a }}$ \\
IE-751 & $1.1 \pm 0.6^{\text {cd }}$ & $1.4 \pm 0.7^{\text {cd }}$ & $1.1 \pm 0.6^{\text {d }}$ & $4.7 \pm 2.5^{\text {ab }}$ \\
IE-752 & $1.6 \pm 0.4^{\text {cd }}$ & $1.8 \pm 0.4^{\text {b-d }}$ & $1.2 \pm 1.4^{\text {cd }}$ & $5.3 \pm 3.7^{\mathrm{a}}$ \\
IE-754 & $1.4 \pm 0.7^{\text {cd }}$ & $1.6 \pm 0.7^{\text {cd }}$ & $1.6 \pm 0.7^{\text {cd }}$ & $5.0 \pm 1.6^{\mathrm{a}}$ \\
IE-755 & $1.3 \pm 0.7^{\text {cd }}$ & $2.2 \pm 0.4^{\text {b-d }}$ & $1.0 \pm 0.5^{\text {d }}$ & $5.4 \pm 2.4^{\mathrm{a}}$ \\
\hline
\end{tabular}

MEA: malt extract medium - extrait de malt; YMEA : malt extract medium with yeast extract - extrait de malt avec de l'extrait de levure; YMEA-indulin AT : malt extract medium with yeast extract and indulin AT - extrait de malt avec de l'extrait de levure et de l'induline AT; CMEA : malt extract medium with compost extract - extrait de malt avec de l'extrait de compost; Values are means \pm standard deviation of eight replicates. Values in columns or rows followed by the same letters are equal ( $p<0.05$, Duncan) - Les valeurs sont des moyennes \pm écarts types de huit répétitions. Les valeurs dans les colonnes ou les lignes suivies des mêmes lettres sont égales ( $\mathrm{p}<0,05$, Duncan).

Table 2. Mycelial growth rates $\left(\mathrm{mm} \cdot \mathrm{day}^{-1}\right)$ obtained by Agaricus bisporus strains on different culture media at $25{ }^{\circ} \mathrm{C}-$ Taux de croissance mycélienne $\left(\mathrm{mm} \cdot j\right.$ jour $\left.\mathrm{r}^{-1}\right)$ des souches d'Agaricus bisporus sur différents milieux de culture à $25^{\circ} \mathrm{C}$.

\begin{tabular}{lllll}
\hline Strain & MEA & YMEA & $\begin{array}{l}\text { YMEA- } \\
\text { indulin } \\
\text { AT }\end{array}$ & CMEA \\
\hline Wild & & & \\
IE-623 & $2.8 \pm 0.7^{\mathrm{b}-\mathrm{d}}$ & $2.6 \pm 0.6^{\mathrm{b}-\mathrm{d}}$ & $2.8 \pm 1.0^{\mathrm{b}-\mathrm{d}}$ & $6.4 \pm 1.7^{\mathrm{a}}$ \\
IE-746 & $3.7 \pm 0.7^{\mathrm{ab}}$ & $3.4 \pm 0.6^{\mathrm{ab}}$ & $3.5 \pm 0.7^{\mathrm{ab}}$ & $4.9 \pm 1.6^{\mathrm{a}}$ \\
\hline Commercial & & & \\
IE-273 & $1.4 \pm 0.2^{\mathrm{de}}$ & $1.3 \pm 0.5^{\mathrm{de}}$ & $1.3 \pm 0.4^{\mathrm{de}}$ & $2.9 \pm 0.9^{\mathrm{b}-\mathrm{d}}$ \\
IE-610 & $2.8 \pm 0.3^{\mathrm{b}-\mathrm{d}}$ & $3.3 \pm 0.5^{\mathrm{a}-\mathrm{c}}$ & $2.5 \pm 0.7^{\mathrm{b}-\mathrm{e}}$ & $6.2 \pm 2.4^{\mathrm{a}}$ \\
IE-751 & $1.1 \pm 0.3^{\mathrm{de}}$ & $2.3 \pm 0.8^{\mathrm{b}-\mathrm{e}}$ & $0.8 \pm 0.5^{\mathrm{e}}$ & $5.0 \pm 3.2^{\mathrm{a}}$ \\
IE-752 & $1.2 \pm 0.5^{\mathrm{de}}$ & $2.4 \pm 0.6^{\mathrm{b}-\mathrm{e}}$ & $1.1 \pm 0.2^{\mathrm{e}}$ & $5.8 \pm 3.1^{\mathrm{a}}$ \\
IE-754 & $3.1 \pm 0.3^{\mathrm{bc}}$ & $3.0 \pm 0.5^{\mathrm{bc}}$ & $1.6 \pm 0.5^{\mathrm{c}-\mathrm{e}}$ & $5.9 \pm 2.4^{\mathrm{a}}$ \\
IE-755 & $1.9 \pm 0.5^{\mathrm{c}-\mathrm{e}}$ & $1.7 \pm 0.4^{\mathrm{c}-\mathrm{e}}$ & $1.1 \pm 0.3^{\mathrm{e}}$ & $6.1 \pm 2.6^{\mathrm{a}}$ \\
\hline
\end{tabular}

Legend - légende: see table 1 - voir tableau 1. 
Table 3. Mycelial growth rates $\left(\mathrm{mm} \cdot \mathrm{day}^{-1}\right)$ obtained by Agaricus bisporus strains on different culture media at $28{ }^{\circ} \mathrm{C}-$ Taux de croissance mycélienne $\left(\mathrm{mm} \cdot j\right.$ jour $\left.\mathrm{r}^{-1}\right)$ des souches d'Agaricus bisporus sur différents milieux de culture à $28^{\circ} \mathrm{C}$.

\begin{tabular}{|c|c|c|c|c|}
\hline Strain & MEA & YMEA & $\begin{array}{l}\text { YMEA- } \\
\text { indulin } \\
\text { AT }\end{array}$ & CMEA \\
\hline \multicolumn{5}{|l|}{ Wild } \\
\hline IE-623 & $3.6 \pm 0.6^{\mathrm{ab}}$ & $2.7 \pm 0.3^{\mathrm{b}-\mathrm{e}}$ & $3.3 \pm 0.7^{\mathrm{bc}}$ & $6.0 \pm 1.8^{\mathrm{a}}$ \\
\hline IE-746 & $4.0 \pm 0.4^{\mathrm{ab}}$ & $3.4 \pm 0.8^{\mathrm{bc}}$ & $3.8 \pm 0.7^{\mathrm{ab}}$ & $5.6 \pm 2.2^{\mathrm{a}}$ \\
\hline \multicolumn{5}{|c|}{ Commercial } \\
\hline IE-273 & $1.6 \pm 0.2^{\mathrm{de}}$ & $1.6 \pm 0.3^{\mathrm{de}}$ & $1.2 \pm 0.4^{\mathrm{de}}$ & $3.2 \pm 1.3^{\mathrm{b}-\mathrm{c}}$ \\
\hline IE-610 & $2.8 \pm 0.5^{\mathrm{b}-\mathrm{d}}$ & $3.3 \pm 0.7^{\mathrm{bc}}$ & $3.5 \pm 0.9^{\mathrm{bc}}$ & $6.1 \pm 2.1^{\mathrm{a}}$ \\
\hline IE-751 & $1.6 \pm 0.4^{\mathrm{de}}$ & $1.9 \pm 0.6^{\mathrm{c}-\mathrm{e}}$ & $0.9 \pm 0.6^{\mathrm{e}}$ & $5.2 \pm 2.6^{\mathrm{a}}$ \\
\hline IE-752 & $1.5 \pm 0.6^{\mathrm{de}}$ & $2.5 \pm 0.6^{\mathrm{b}-\mathrm{e}}$ & $1.2 \pm 0.4^{\mathrm{de}}$ & $6.2 \pm 3.1^{\mathrm{a}}$ \\
\hline IE-754 & $2.2 \pm 0.3^{\mathrm{b}-\mathrm{e}}$ & $3.2 \pm 0.7^{\mathrm{b}-\mathrm{d}}$ & $1.1 \pm 0.2^{\mathrm{e}}$ & $6.3 \pm 2.0^{\mathrm{a}}$ \\
\hline IE-755 & $1.7 \pm 0.5^{\mathrm{c}-\mathrm{e}}$ & $2.6 \pm 0.7^{\mathrm{b}-\mathrm{e}}$ & $1.6 \pm 0.6^{\mathrm{de}}$ & $6.1 \pm 2.4^{\mathrm{a}}$ \\
\hline
\end{tabular}

Legend - légende: see table 1 - voir tableau 1.

evaluated, the commercial strain IE-273 had the lowest growth rate, regardless of the temperature or culture media. Significant differences were underlined by ANOVA according to strain, culture medium and temperature and to the interaction between strain and culture medium.

The mycelial growth pattern of the strains varied during the 14 days we evaluated incubation. The Mexican wild strain IE-623 had the highest mycelial increases in the CMEA medium during the first week, and the other Mexican strain (IE-746) in media containing yeast extract (YMEA and YMEA-indulin AT). The remaining strains grew better in CMEA and MEA media. From the second week of incubation, cultures reached the highest values in the CMEA medium, especially when incubated at 25 and $28^{\circ} \mathrm{C}$.

The wide variability in the response observed in the first days of incubation is probably because the strains required different pre-adaptation times, and humic species such as $A$. bisporus grow at low $\mathrm{C} / \mathrm{N}$ ratios and prefer organic $\mathrm{N}$ sources. Our results coincide with those of other authors (Kalmis et al., 2005; Liu \& Wang, 2009) who reported that yeast extract supplementation increases the mycelial growth of Agaricus spp.; while compost extract has been reported to be an accelerant of mycelial growth for other edible mushroom species (Rainey, 1989).

The significant differences observed in the strains could indicate that some of the variation in their responses depended not only on their ability to use nutrient sources, but also on their tolerance to other chemical compounds present in the culture media.
With respect to the temperatures, the ones evaluated here seem to cover an acceptable range for the adequate mycelial growth of the strains, especially for the wild strains.

\subsection{Effect of strains and temperature on the degradation of lignin-derived phenol content in different basal media}

The results of this experiment at $22{ }^{\circ} \mathrm{C}$ showed that the Mexican wild strain IE-623 was the most efficient to degrade phenolic compounds in the medium containing yeast extract, reaching similar values to the commercial strain (IE-752) with no significant difference. At $25^{\circ} \mathrm{C}$, the Mexican strain (IE-746) was the most efficient to degrade phenolic compounds in both media, while at $28{ }^{\circ} \mathrm{C}$, the degradative capacity of the wild strains decreased, especially in the cultures in CME (Table 4). This is very important from a biotechnological point of view for strains selection as the removal and transformation of phenolic compounds by edible mushroom species have received attention in the recent years (Kameda et al., 2006).

Statistical analysis detected significant differences between strains, culture media and temperatures. In general, cultivating the strains in YME medium favored the loss of phenol content from the cultures. For incubation temperature, the pattern varied depending on the strain, though for the cultures kept at $22{ }^{\circ} \mathrm{C}$ the media lost more of their phenol content during the growth of the fungi.

Among strains, wild strain IE-746 had a high capacity to reduce the phenol concentration in the media, independently of supplementation, and especially in the cultures incubated at $25^{\circ} \mathrm{C}$. Additionally, commercial strains IE-754 and IE-752 had the same high capacity at 22 and $28{ }^{\circ} \mathrm{C}$, respectively.

The small decrease in phenol concentration in CME medium could be due to the chemical composition of the extract, which comes from a selective substrate for Agaricus mushrooms, resulting from aerobic fermentation. This might have favored the breakdown of the glycosidic links of lignocellulose and made the monosaccharides that are used as a carbon source available; the strains initially use these simple compounds and subsequently act on other more complex compounds, such as aromatics. This pattern has been observed in other edible species, such as Pleurotus spp., when it is cultivated in substrates with a high tannin and phenol content, such as coffee pulp (Salmones et al., 2005).

\subsection{Mushroom production yield}

For carpophore production, the time required for mycelial colonization on the compost varied little 
Table 4. Effect of temperature on the decrease of lignin-derived phenolic concentrations $\left(\mathrm{mm} \cdot \mathrm{l}^{-1}\right)$ of Agaricus bisporus strains cultured in YME and CME - Effet de la température sur la diminution des concentrations phénoliques dérivées de la lignine $\left(\mathrm{mm} \cdot \mathrm{l}^{-1}\right)$ des souches d'Agaricus bisporus cultivées sur YME et CME.

\begin{tabular}{|c|c|c|c|c|c|c|}
\hline \multirow[t]{2}{*}{ Strain } & \multicolumn{2}{|l|}{$22^{\circ} \mathrm{C}$} & \multicolumn{2}{|l|}{$25^{\circ} \mathrm{C}$} & \multicolumn{2}{|l|}{$28^{\circ} \mathrm{C}$} \\
\hline & YME & CME & YME & CME & YME & CME \\
\hline \multicolumn{7}{|l|}{ Wild } \\
\hline IE-623 & $0.58 \pm 0.02^{\mathrm{a}}$ & $0.89 \pm 0.02^{\mathrm{b}}$ & $0.73 \pm 0.04^{b}$ & $0.91 \pm 0.03^{\mathrm{e}-\mathrm{g}}$ & $0.74 \pm 0.03^{\mathrm{b}-\mathrm{d}}$ & $0.99 \pm 0.02^{\mathrm{f}}$ \\
\hline IE-746 & $0.61 \pm 0.02^{\mathrm{ab}}$ & $0.69 \pm 0.1^{\mathrm{ab}}$ & $0.48 \pm 0.13^{\mathrm{a}}$ & $0.57 \pm 0.03^{\mathrm{a}}$ & $0.65 \pm 0.03^{\mathrm{ab}}$ & $0.80 \pm 0.04^{c-e}$ \\
\hline \multicolumn{7}{|c|}{ Commercial } \\
\hline IE-273 & $0.63 \pm 0.02^{\mathrm{ab}}$ & $0.81 \pm 0.03^{\mathrm{ab}}$ & $0.75 \pm 0.03^{\mathrm{bc}}$ & $0.99 \pm 0.01^{\mathrm{g}}$ & $0.73 \pm 0.04^{\mathrm{a}-\mathrm{c}}$ & $0.99 \pm 0.04^{\mathrm{f}}$ \\
\hline IE-610 & $0.63 \pm 0.02^{\mathrm{ab}}$ & $0.53 \pm 0.01^{\mathrm{a}}$ & $0.88 \pm 0.01^{\mathrm{c}-\mathrm{f}}$ & $0.93 \pm 0.02^{\mathrm{fg}}$ & $0.62 \pm 0.03^{\mathrm{a}}$ & $0.88 \pm 0.05^{\mathrm{e}}$ \\
\hline IE-751 & $0.59 \pm 0.01^{\mathrm{ab}}$ & $0.71 \pm 0.01^{\mathrm{ab}}$ & $0.72 \pm 0.02^{\mathrm{b}}$ & $0.76 \pm 0.02^{\mathrm{b}-\mathrm{d}}$ & $0.72 \pm 0.04^{\mathrm{a}-\mathrm{c}}$ & $0.87 \pm 0.04^{\mathrm{e}}$ \\
\hline IE-752 & $0.58 \pm 0.05^{\mathrm{a}}$ & $0.76 \pm 0.02^{\mathrm{ab}}$ & $0.76 \pm 0.03^{\mathrm{b}-\mathrm{d}}$ & $0.81 \pm 0.04^{\mathrm{b}-\mathrm{f}}$ & $0.66 \pm 0.05^{\mathrm{ab}}$ & $0.86 \pm 0.05^{\text {de }}$ \\
\hline IE-754 & $0.75 \pm 0.03^{\mathrm{ab}}$ & $0.82 \pm 0.01^{\mathrm{ab}}$ & $0.79 \pm 0.03^{\mathrm{b}-\mathrm{e}}$ & $0.88 \pm 0.03^{\mathrm{d}-\mathrm{f}}$ & $0.71 \pm 0.03^{\mathrm{a}-\mathrm{c}}$ & $0.78 \pm 0.02^{\mathrm{c}-\mathrm{e}}$ \\
\hline IE-755 & $0.69 \pm 0.04^{\mathrm{ab}}$ & $0.82 \pm 0.02^{\mathrm{ab}}$ & $0.77 \pm 0.04^{\mathrm{b}-\mathrm{d}}$ & $0.83 \pm 0.02^{\mathrm{b}-\mathrm{f}}$ & $0.73 \pm 0.01^{\mathrm{a}-\mathrm{c}}$ & $0.79 \pm 0.01^{\mathrm{c}-\mathrm{e}}$ \\
\hline
\end{tabular}

YME: yeast malt extract - extrait de malt et de levure; CME: compost malt extract - extrait de malt et de compost; Values are means \pm standard deviation of eight replicates. Values in columns or rows followed by the same letters are equal $(p<0.05$, Duncan $)-$ Les valeurs sont des moyennes \pm écarts-types de huit répétitions. Les valeurs dans les colonnes ou les lignes suivies des mêmes lettres sont égales ( $\mathrm{p}<0,05$, Duncan).

among the strains, requiring $28 \pm 2$ days of incubation, whereas on the casing mixture growth was observed 11 to 14 days after application. The strains had crop cycles lasting 74 to 98 days, during which three flushes were evaluated.

Primordium initiation, or earliness, was observed 36 (IE-623) to 43 (IE-746) days from the spawning day of the samples (Table 5) and the basidiomes required 6 to 8 days to reach their maximum development, since they were harvested with caps extended. These incubation values are similar to those reported by Pardo et al. (2004), who cultivated A. bisporus commercial strains on different casing mixtures and recorded 14 days for the colonization period and 38-42.1 days to obtain the first crop during crop cycles of 80 days.

The biological efficiency (BE) obtained for wild strains (Table 5) was 50.8 to $61.9 \%$, and $95.5 \%$ for the commercial germplasm. Tukey's multiple range test applied to the means for production determined that the $\mathrm{BE}$ values of the commercial strains were statistically different from those of the wild strains. These BE values are higher than reported by Martínez-Carrera et al. (2001) for Mexican wild strains of Agaricus spp., and similar to those reported in previous studies by, for example, Mamiro \& Royse (2008) and Andrade et al. (2008, 2013), but lower than those reported by Bechara et al. (2005), Altieri et al. (2009), Royse \& Chalupa (2009) and Gea et al. (2012), who recorded values higher than $100 \%$ with commercial strains grown in mixtures of composite and non-composite materials. With respect to the previous results, Agaricus production is generally reported when the pileus has not yet opened, therefore it is not possible to rigorously compare our results with those of previous studies. However, taking this into consideration the values we recorded seem to lie within the range reported in the literature.

Production rates obtained for the Mexican wild strains were 0.63 to $0.73 \%$, and 1.14 to $1.19 \%$ for commercial strains, with yields of $7.4 \%$ (IE-623) to $14.1 \%$ (IE-754) (Table 5). The production rate of the commercial and wild strains differed significantly. In general, the results obtained for commercial strains in this study were consistent with values reported previously (Weil et al., 2006; Mamiro \& Royse, 2008), suggesting that further experiments are needed to determine which nutrient(s) and other environmental interactions might be involved in increasing mushroom yield from native germplasm.

Regarding the diameter of the pileus developed by the different strains, the G2 and G3 size categories were the most frequently observed in all samples (Figure 1), representing $93.1 \%$ (IE-623) to $95.3 \%$ (IE-746) of the total production in wild strains, and $95.8 \%$ (IE-752) to $96.2 \%$ (IE-754) in the commercial strains. Only commercial strain IE-754 developed a pileus greater than $15 \mathrm{~cm}$ in diameter (G4). Moreover, even if the cap color was not considered in the present study, a light brown coloration of the wild strains was recorded whereas the commercial strains exhibit white caps.

The pileus diameters recorded for our strains are comparable to the values of $7.24-10.2 \mathrm{~cm}$ reported by 
Table 5. Production of fruiting bodies by Agaricus bisporus strains on compost - Production de carpophores par différentes souches d'Agaricus bisporus cultivées sur compost.

\begin{tabular}{|c|c|c|c|c|c|}
\hline Strain & Earliness (days) & Culture cycle (days) & Biological efficiency (\%) & Yield $\left(\mathrm{kg} \cdot \mathrm{m}^{-2}\right)$ & Production rate $(\%)$ \\
\hline \multicolumn{6}{|l|}{ Wild } \\
\hline IE-623 & $36-39$ & $75-88$ & $50.8 \pm 15.1^{\mathrm{c}}$ & $7.40 \pm 2.1^{\mathrm{b}}$ & $0.63 \pm 0.3^{\mathrm{b}}$ \\
\hline IE-746 & $40-43$ & $88-91$ & $61.9 \pm 26.4^{\mathrm{bc}}$ & $8.83 \pm 4^{b}$ & $0.73 \pm 0.3^{\mathrm{b}}$ \\
\hline \multicolumn{6}{|c|}{ Commercial } \\
\hline IE-752 & $41-42$ & $74-83$ & $95.5 \pm 6.5^{\mathrm{ab}}$ & $13.80 \pm 1^{\mathrm{a}}$ & $1.14 \pm 0.4^{\mathrm{a}}$ \\
\hline IE-754 & 38 & $81-98$ & $95.5 \pm 19.5^{\mathrm{a}}$ & $14.10 \pm 2.9^{\mathrm{a}}$ & $1.19 \pm 0.2^{\mathrm{a}}$ \\
\hline
\end{tabular}

Values are means \pm standard deviation of eight replicates. Values in columns or rows followed by the same letters are equal $(p<0.05$, Duncan) - Les valeurs sont des moyennes \pm écarts-types de huit répétitions. Les valeurs dans les colonnes ou les lignes suivies des mêmes lettres sont égales ( $\mathrm{p}<0,05$, Duncan).

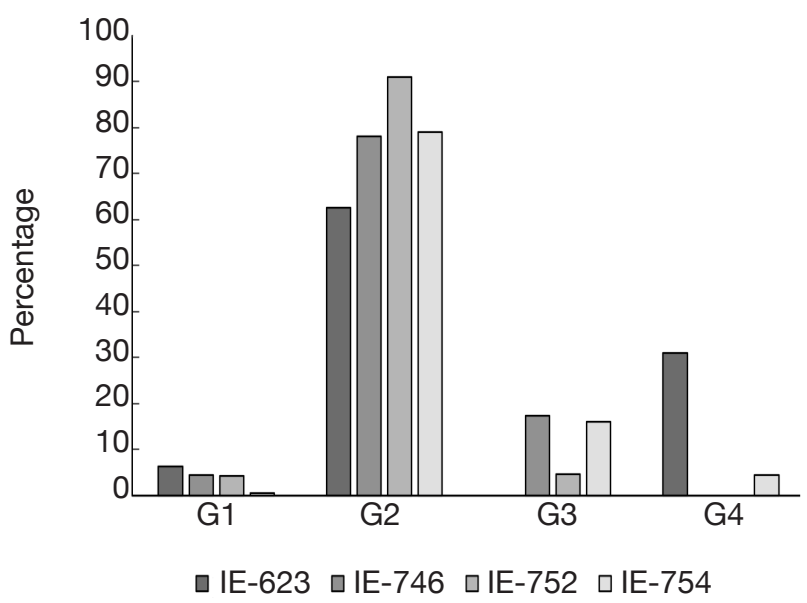

Figure 1. Percentage of fruiting bodies obtained from Agaricus bisporus strains, grouped by pileus diameters Pourcentage des fructifications des souches d'Agaricus bisporus regroupés par diamètre du chapeau.

$\mathrm{G} 1: \leq 5 \mathrm{~cm} ; \mathrm{G} 2:$ 5.1-10 cm; G3: 10.1-14.9 cm; G4: > $15 \mathrm{~cm}$.

Wang et al. (2010), $37 \mathrm{~mm}$ by Straatsma et al. (2013), and $33.3 \mathrm{~mm}$ reported by Pardo-Giménez \& PardoGonzález (2008) in commercial cultures of Spanish strains, and are considered an acceptable size for commercialization.

\section{CONCLUSIONS}

Adequate mycelial growth and the conservation of germplasm are priorities in the biotechnology of mushroom cultivation, since they are the source for the production of the inoculum. Incorporating yeast and compost extract into the basal media favored the mycelial growth rate of the Agaricus strains studied.

Wild strains had good mycelial growth and a good capacity to produce fruiting bodies, but their mushroom production values were lower than those of the commercial strains. However, despite the low productivity, it is possible that these strains have adaptive advantages to the local environment which would allow them to be more competitive. Additional work is needed to determine the effect of increasing the ambient temperature $\left(28^{\circ} \mathrm{C}\right.$ or more) during primordium initiation and mushroom development stages, and to evaluate the effect of adding supplements to the inoculum or compost with the goal of improving productivity parameters. In order to offer some strains with characteristics adapted to the substrates and local environment, it will also be necessary to perform growth and fruiting tests using local substrates.

\section{Acknowledgements}

This work was support by Institute of Ecology (INECOL) and CONACyT (project Fomix 94242). The authors thank Dr S.P. Wasser and J.C. Sucarrats for providing some strains.

\section{Bibliography}

Altieri R. et al., 2009. Performance of olive mill solid waste as a constituent of the substrate in commercial cultivation of Agaricus bisporus. Int. Biodeterior. Biodegrad., 63, 993-997.

Andrade M.C.N.D., Zied D.C., $\quad$ Minhoni M.T.D.A. \& Kopytowski Filho J., 2008. Yield of four Agaricus bisporus strains in three compost formulations and chemical composition analyses of the mushrooms. Braz. J. Microb., 39, 593-598.

Andrade M.C.N.D. et al., 2013. Dynamics of the chemical composition and productivity of composts for the cultivation of Agaricus bisporus strains. Braz. J. Microb., 44, 1139-1146.

Bechara M.A., Heinemann P., Walker P.N. \& Romaine C.P., 2005. Cultivation of Agaricus bisporus on a mixture of cereal grain spawn and delayed-release nutrient supplement. Mushroom News, 53, 6-10. 
Box J.D., 1983. Investigation of the Folin-Ciocalteau phenol reagent for the determination of polyphenolic substances in natural waters. Water Res., 17, 511-525.

Callac P., Theochari I. \& Kerrigan R.W., 2005. The germplasm of Agaricus bisporus: main results after ten years of collecting in France, in Greece, and in North America. Acta Hortic., 579, 49-55.

Gaitán-Hernández R., Cortés N. \& Mata G., 2014. Improvement of yield of shiitake on wheat straw by use of supplemented spawn. Braz. J. Microb., 45, 467-474.

Gea J.F. et al., 2012. Effect of spent mushroom compost tea on mycelial growth and yield of button mushroom (Agaricus bisporus). World J. Microbiol. Biotechnol., 28, 2765-2769.

Geml J., Laursen G.A. \& Taylor D.L., 2008. Molecular diversity assessment of arctic and boreal Agaricus taxa. Mycologia, 100, 577-589.

Hildén K., Mäkelä M.R., Lankinen P. \& Lundell T., 2013. Agaricus bisporus and related Agaricus species on lignocellulose: production of manganese peroxidase and multicopper oxidases. Fungal Genet. Biol., 55, 32-41.

Kalmis E., Solak M.\& Kalyoncu F., 2005. Determination of some characteristics of wild Agaricus bisporus collected from Turkey. Acta Edulis Fungi, 12, 95-99.

Kameda E., Langone M.A.P. \& Coelho M.A.Z., 2006. Tyrosinase extracts from Agaricus bisporus mushroom and its in natura tissue for specific phenol removal. Environ. Technol., 27, 1209-1215.

Largeteau M.L., Callac P., Navarro-Rodriguez A.M. \& Savoie J.M., 2011. Diversity in the ability of Agaricus bisporus wild isolates to fruit at high temperature $\left(25^{\circ} \mathrm{C}\right)$. Fungal Biol., 115, 1186-1195.

Liu G.Q. \& Wang X.L., 2009. Selection of a culture medium for reducing costs and enhancing biomass and intracellular polysaccharide production by Agaricus blazei AB2003. Food Technol. Biotechnol., 47, 210-214.

Mamiro D.P. \& Royse D.J., 2008. The influence of spawn type and strain on yield, size and mushroom solids content of Agaricus bisporus produced on noncomposted and spent mushroom compost. Bioresour. Technol., 99, 3205-3212.

Mantovani T.R., Linde G.A. \& Colauto N.B., 2007. Effect of the addition of nitrogen sources to cassava fiber and carbon-to-nitrogen ratios on Agaricus brasiliensis growth. Can. J. Microb., 53, 139-143.

Martínez-Carrera D. et al., 2001. Characterisation and cultivation of wild Agaricus species from Mexico. Micologia Apl. Int., 13, 9-24.

Martinez-Carrera D. \& Lopez-Martinez De Alva L., 2010. Historia del cultivo comercial de hongos comestibles en México: éxitos y fracasos durante el periodo 1991-2009. In: Martinez-Carrera D. et al., eds. Hacia un desarrollo sostenible del sistema de producción-consumo de los hongos comestibles y medicinales en Latinoamérica, avances y perspectiva en el siglo XXI. Montecillo, Mexico: Colegio de Postgraduados, 513-551.
Martínez-Carrera D. et al., 2016. Contribución de los hongos comestibles funcionales y medicinales a la construcción de un paradigma sobre la producción, la dieta, la salud y la cultura en el sistema agroalimentario de México. In: Martínez-Carrera D. \& Ramírez Juárez J., eds. Ciencia, tecnología e innovación en el sistema agroalimentario de México. Texcoco, Mexico: Colegio de PosgraduadosAMC-CONACYTUPAEP-IMINAP, 581-640.

Mata G. \& Rodríguez Estrada A.E., 2005. Viability in spawn stocks of the white button mushroom, Agaricus bisporus, after freezing in liquid nitrogen without a cryoprotectant. J. Agric. Technol., 1, 153-162.

Mata G. et al., 2016. Primer registro de Agaricus bisporus (Basidiomycota, Agaricaceae) silvestre en Tlaxcala y Veracruz, México. Rev. Mex. Biodivers., 87, 10-17.

Navarro C.P. \& Savoie J.M., 2015. Selected wild strains of Agaricus bisporus produce high yields of mushrooms at $25^{\circ} \mathrm{C}$. Rev. Iberoam. Micologia, 32, 54-58.

Nogueira De Andrade M.C., Chavari J.L., Teixeira De Almeida M. \& Cunha Zied M.D., 2010. Crescimento micelial in vitro de cinco linhagens de Agaricus bisporus submetidas a diferentes condições de temperatura. Acta Scientiarum Agron., 32, 69-72.

Pardo A., de Juan A.J., Pardo J. \& Pardo J.E., 2004. Assessment of different casing materials for use as peat alternative for mushroom cultivation, evaluation of quantitative and qualitative production parameters. Span. J. Agric. Res., 2, 267-272.

Pardo-Giménez A. \& Pardo-González J.E., 2008. Evaluation of casing materials made from mushroom substrate and coconut fibre pith for use in production of Agaricus bisporus (Lange) Imbach. Span. J.Agric. Res., 6, 683-690.

Patyshakuliyeva A. et al., 2013. Carbohydrate utilization and metabolism is highly differentiated in Agaricus bisporus. BMC Genomics, 14, 663.

Rainey P.B., 1989. A new laboratory medium for the cultivation of Agaricus bisporus. N. Z. Nat. Sci., 16, 109-112.

Royse D.J., 2014. A global perspective on the high five: Agaricus, Pleurotus, Lentinula, Auricularia \& Flammulina. In: Singh M., ed. Proceedings of the $8^{\text {th }}$ International Conference on Mushroom Biology and Mushroom Products (ICMBMP8), 19-22 November, 2014, New Delhi, India. New Delhi: World Society of Mushroom Biology and Mushroom Products ICARDirectorate of Mushroom Research Mushroom Society of India, 1-6.

Royse D.J. \& Chalupa W., 2009. Effects of spawn, supplement and phase II compost additions and time of re-casing second break compost on mushroom (Agaricus bisporus) yield and biological efficiency. Bioresour. Technol., 100, 5277-5282.

Royse J.D. \& Sánchez J.E., (in press). Producción mundial de setas Pleurotus spp. con énfasis en países iberoamericanos. In: Sánchez J.E. \& Royse D.J., eds. La biología, el cultivo y las propiedades nutricionales 
y medicinales de las setas Pleurotus spp. San Cristobal de las Casas, Chis., Mexico: El Colegio de la Frontera Sur, 1-9.

Salmones D., Mata G. \& Waliszewski K.N., 2005. Comparative culturing of Pleurotus spp. on coffee pulp and wheat straw: biomass production and substrate biodegradation. Bioresour. Technol., 96, 537-544.

Savoie J.M., Foulongne-Oriol M., Barroso G. \& Callac P., 2013. Genetics and genomics of cultivated mushrooms, application to breeding of Agarics. In: Esser K., ed. The mycota: a comprehensive treatise on fungi as experimental systems for basic and applied research. Agricultural Applications XI. Berlin, Germany: Springer, 3-33.

Sonnenberg A.S.M. et al., 2011. Breeding and strains protection in the button mushroom Agaricus bisporus. In: Savoie J.M., Foulongme-Oriol M., Largeteau M. \& Barroso G., eds. Proceedings of the $7^{\text {th }}$ International Conference on Mushroom Biology and Mushroom
Products (ICMBMP7), 4-7 October, 2011, Arcachon, France. Arcachon, France: World Society of Mushroom Biology and Mushroom Products, 7-15.

Straatsma G., Sonnenberg A.S. \& Van Griensven L.J., 2013. Development and growth of fruit bodies and crops of the button mushroom, Agaricus bisporus. Fungal Biol., 117, 697-707.

Wang Q., Li B.B., Li H. \& Han J.R., 2010. Yield, dry matter and polysaccharides content of the mushroom Agaricus blazei produced on asparagus straw substrate. Sci. Hortic., 125, 16-18.

Wang Z.S. et al., 2004. Thermotolerance-related genes in Agaricus bisporus. Mushroom Sci., 16, 133-137.

Weil D.A., Beelman R.B. \& Beyer D.M., 2006. Manganese and other micronutrient additions to improve yield of Agaricus bisporus. Bioresour. Technol., 97, 1012-1017.

(37 ref.) 